\title{
Review and typification of names of taxa proposed by J. Planellas Giralt (1820-1888)
}

\author{
Roser Guàrdia1 \& Ignasi Soriano1,2 \\ 1 Centre of Documentation of Plant Biodiversity (CeDocBiV), University of Barcelona, Baldiri Reixac 2, 08028 Barcelona, Spain \\ 2 Department of Plant Biology, University of Barcelona, Diagonal 643, 08028 Barcelona, Spain \\ Author for correspondence: Roser Guàrdia, cedocbiv@ub.edu \\ ORCID RG, http://orcid.org/0000-0002-5304-968X; IS, http://orcid.org/0000-0003-3875-7511 \\ DOI http://dx.doi.org/10.12705/651.14
}

Abstract Vascular plant names proposed by Planellas were reviewed and, when necessary and possible, typified. Eight lectotypes and one neotype have been designated.

Keywords Galician flora; Iberian Peninsula; lectotypification; neotypification; vascular flora

\section{INTRODUCTION}

The Spanish botanist José Planellas Giralt (1820-1888) studied the Galician flora intensely between 1847 and 1868, when he was professor of Botany at the University of Santiago de Compostela. His herbarium was the basis for his major botanical contribution: Ensayo de una flora fanerogámica gallega (Planellas, 1852; henceforth Ensayo) the first pharmacological Galician flora. In this work he recorded 853 taxa with their medicinal uses and described 12 new taxa. When Planellas moved to Barcelona in 1868 , he brought with him the main part of his herbarium, which is now housed in BCN. A small part of the collection (185 specimens) remained in Santiago de Compostela, now conserved at the Museum of Natural History Luis Iglesias of the University of Santiago de Compostela (http://revistas.usc. es/export/sites/default/museohn/descargas/Herbario_Planellas. pdf). Planellas maintained an active scientific relationship with H.M. Willkomm (1821-1895). In the Prodromus florae hispanicae (Willkomm \& Lange, 1861-1880), about 400 citations of specimens of Planellas are listed and atleast 16 herbarium sheets collected by Planellas are included in the Willkomm Herbarium conserved in Coimbra (http://www.uc.pt/en/herbario_digital/ willkomm_herbarium/herb_on_line). Around 1920, the botanist C. Pau (1857-1937) studied the Galician plants of the Planellas herbarium and published an extensive review (Pau, 1921a, b, 1922, 1924). Surprisingly, some of these specimens have now been found in MA. We presume that during his study Pau took with him several sheets on loan from the Planellas herbarium and did not return them. Later, these sheets were probably incorporated into MA togetherwith the rest of the Pau collections, as the MA herbarium numbers correlate with those of the other herbarium sheets of Pau in this herbarium (cf. Carrasco, 1975).

As part of a wider study on the Planellas herbarium, the presentpaperdeals with the plantnames proposed by Planellas; we have revised their current status and, when possible, types were designated.

\section{RESULTS}

The 12 taxa proposed by Planellas in his Ensayo, were described with no reference to any particular specimen, a rather vague indication of the localities, and were always undated. Similarly, the herbarium sheets of these taxa have the same imprecise localities and are also undated; almost all the labels were handwritten and signed by Planellas and several have notations as "mihi" or "sp. nova". Therefore, we assume that the main source of original material for Planellas names was his herbarium. Another argument that supports this assumption is the fact that in the Ensayo Planellas indicated for each species if he had observed and collected it (V.v. [Vidi vivam]) or if he had only observed it as a dried specimen (V.s. [Vidi siccam]). These indications correspond well with his herbarium composition: plants indicated as "V.v." have Planellas handwritten labels and he figures as collector, and those with "V.s." always correspond to specimens collected by another botanist.

Eight of the Planellas names are legitimate and four are illegitimate because they are later homonyms. Until now, only one of the names has been lectotypified: Silene littoralis Planellas (Talavera \& Muñoz Garmendia, 1989). We have designated here eight lectotypes and one neotype. For the remaining two names, the designation of types was not possible because we have been unable to find any original material or other appropriate specimens. Specialists of these taxonomical groups will do it more properly.

We list below all the taxa attributed to Planellas. For each name we provide the Latin name, author and place of publication, the synonyms (name in current use according to Flora iberica (Castroviejo \& al., 1986-), the original locality as cited in the protologue and the abbreviations "V. v." and/or "V. s." (see above). When possible, we have designated the type with the respective herbarium number and the transcription of the original label. Notes have been added wherever appropriate. 
Anthoxanthum angustifolium Planellas, Ensayo Fl. Gallega: 398. 1852 - Ind. loc.: "Crece en los montes estériles y es común en el de la Almáciga (Sant. ${ }^{\circ}$ ) [Santiago de Compostela] ... V.v." - Lectotype (designated here): Procedente de los campos del monte de la Almáciga, Sant ${ }^{\circ}$ [Santiago de Compostela], Galicia, J. Planellas s.n. (BCN No. 83816!). [=Anthoxanthum aristatum Boiss.]

Dianthus caespitosifolius Planellas, Ensayo Fl. Gallega: 118. $1852 \equiv$ Dianthus laricifolius var. caespitosifolius (Planellas) Pau in Brotéria, Sér. Bot. 19: 59. 1921 三Dianthus laricifolius subsp. caespitosifolius (Planellas) M.Laínz, Aport. Conoc. Fl. Gallega 6: 6. 1968 三Dianthus planellae Willk., Icon. Descr. P1. Nov. 1: 79, t. 53. 1854, nom. illeg. - Ind. loc.: "Crece en los terrenos áridos del Montalegre y en los cascajosos secos del cauce del Miño en Orense ... V.v." - Lectotype (designated here): De los islotes delcauce del Miño en Orense, J. Planellas s.n. (MA barcode MA 33676!).

Note. - There are no specimens of Dianthus caespitosifolius Planellas from this area in the Planellas Herbarium, despite the mention in Pau's revision (1921a: 59). The only sheet of D. caespitosifolius Planellas we have found is conserved in MA, labelled as type although no valid typification has been undertaken.

Dianthus prolifer var. multiflorus Planellas, Ensayo Fl. Gallega: 117.1852. Ind. loc.: "V.v.en Montalegre(Orense)"-Lectotype (designated here): Viñas secas Rosende y entre viñedos, coll. unknown (BCN No.86463!).

[= Petrorhagia prolifera (L.) P.W.Ball \& Heywood]

Note. - There are four sheets of Dianthus prolifer in the Planellas Herbarium, all of them grouped together. We have selected as lectotype the most congruent with the description of Planellas ("heads ovate-globose, with many flowers"); it holds abundant plant material, but no scientific name figures on the label. However, one of the adjacent sheets has two labels, both handwritten by Planellas, one bearing "Dianthus prolifer $\mathrm{Cult}^{\circ}$ [Cultivada] Sant ${ }^{\circ}$ [Santiago]" and the other one only with the taxon name: Dianthus prolifer Linn. v. multiflorus Planellas. Perhaps this last label had been moved accidentally from one sheet to the other.

Lolium glumosum Planellas, Ensayo Fl. Gallega: 409. 1852 Ind. loc.: "Crece en los Agros de Carreiro y en los campos de las márgenes del Sarela ... V.v."

[= Lolium perenne $\mathrm{L}$.]

Note. - No specimens have been found. Pau (1924: 80) did not find any specimens during his review of the herbarium.

Ononis miniana Planellas, Ensayo Fl. Gallega: 166. 1852 ("miñiana") - Ind. loc.: "Observada en el cauce del Miño en Salvatierra y á una legua al O. de Orense, y recibida de Rosende del cauce del Sil ... V. v. y s." - Lectotype (designated here): Del cauce del Miño, J. Planellas s.n. (BCN No. 84761!)

[=Ononis spinosa L. subsp. spinosa $]$
Ornithogalum spicatum Planellas, Ensayo Fl. Gallega: 381. 1852, nom. illeg., non Gaterau, Descr. Pl. Montauban: 72. 1789 - Ind. loc.: "Comun en las colinas del Paraiso y del valle del Viso. ... V. v." - Lectotype (designated here): Del monte de los concheiros, Sant ${ }^{\circ}$ [Santiago de Compostela], J. Planellas s.n. (BCN No.85469!).

[= Ornithogalum broteroi M.Laínz]

Rubus fruticosus var. semipomponius Planellas, Ensayo Fl. Gallega: 194. $1852 \equiv$ Rubus semipomponius (Planellas) Pau in Brotéria, Sér. Brot. 19: 105. 1921 - Ind. loc.: "Es comunísima en los zarzales de todo el pais.... V.v."-Neotype (designated here): De los setos y montes. Agualada, Galicia, Agosto 1866, coll. unknown (BCN No. 86103!). [= Rubus fruticosus L.]

Note. - This is the only specimen conserved in the Planellas Herbarium under this name, but collected 14 years after the publication of the Ensayo.

Saxifraga lepismigena Planellas, Ensayo Fl. Gallega: 224. $1852 \equiv$ Saxifraga clusii var. lepismigena (Planellas) Nyman, Consp. Fl. Eur.: 274. 1879 三 Saxifraga clusii subsp. lepismigena (Planellas) D.A.Webb in Feddes Repert. Spec. Nov. Regni Veg. 68: 199.1963-Ind. loc.: “Crece en los peñascos húmedos inmediatos á los molinos del Noguedo en Santiurjo ... V.s." - Lectotypus (designated here): De los peñascos húmedos inmediatos a los Molinos del Noguedo en Santiurjo, Pérez Méndez s.n. (BCN No. 86163 !).

Scilla monophylla Planellas, Ensayo Fl. Gallega: 380. 1852, nom. illeg., non Link in J. Bot. (Schrader) 2: 319. $1799-$ Ind. loc.: "Común en tierras incultas y pedregosas de los montes del Viso, de Sta. Lucia y en la colina del S. de los prados de Córnes ... V.v."-Lectotype (designated here): Montes delN.O.del Viso, Sant $^{\circ}$ [Santiago de Compostela], J. Planellas s.n. (BCN No.85474!; isolectotype: Museum of Natural History of the University of Santiago de Compostela, herb. Planellas No. 19n.v.).

[= Scilla monophyllos Link.]

Silene littoralis Planellas, Ensayo Fl. Gallega: 123. 1852, nom. illeg., non Pourr. in Hist. \& Mém. Acad. Roy. Sci. Toulouse 3: 329. 1788 - Ind. loc.: "Crece en los arenales de la ría de Pontevedra ... V.v." - Lectotype (designated by Talavera \& Muñoz Garmendia in Anales Jard Bot. Madrid 45: 419. 1989): Arenales de la ría de Pontevedra, J. Planellas s.n. (MA barcode MA 30990!; isolectotype: BCN No. 81416!). [= Silene scabriflora Brot. subsp. scabriflora]

Silene stenophylla Planellas, Ensayo Fl. Gallega: 121. 1852, nom. illeg., non Ledeb., Fl. Ross. 1: 306. 1842 - Ind. loc.: "Crece en los terrenos quebrados lindantes con los arenales de la Isla Tamba [Isla de Tambo] y de Combarro ... V.v." - Lectotype (designated here): Vertientes de las Rías de Pontevedra y Arosa, J. Planellas s.n. (BCN No. 81426!). [=Silene uniflora Roth subsp. uniflora] 
Silene stenophylla var. micra Planellas, Ensayo Fl. Gallega:

121. 1852 - Ind. loc.: "Crece en las vertientes marítimas de la Torre de Hércules é inmediatas al castillo de S. Diego (Coruña) y también en varias otras de la ría de Pontevedra ... V. v."

[= Silene uniflora Roth subsp. uniflora]

Note. - No specimens found, either in $\mathrm{BCN}$ nor other herbaria, but it seems that Pau (1924: 60) saw a specimen during his review of the herbarium.

\section{— LITERATURE CITED}

Carrasco, M.A. 1975. Contribución a la obra taxonómica de Carlos Pau. Trab. Dept. Bot. Univ. Complut. Madrid 8: 1-330.
Castroviejo, S. (coord.) 1986-. Flora iberica: Plantas vasculares de la Península Ibérica e Islas Baleares, 21 vols. Madrid: Real Jardín Botánico, C.S.I.C.

Pau, C. 1921a. El herbario de Planellas. Broteria, Ser. Bot. 19: 49-65.

Pau, C. 1921b. El herbario de Planellas II. Broteria, Ser. Bot. 19: 97-106.

Pau, C. 1922. El herbario de Planellas III. Broteria, Ser. Bot. 20: 120-129.

Pau, C. 1924. El herbario de Planellas IV. Broteria, Ser. Bot. 21: 43-82.

Planellas, J. 1852. Ensayo de una flora fanerogámica gallega. Santiago [de Compostela]: imprenta y litografía de D. Juan Rey Romero.

Talavera, S. \& Muñoz Garmendia, F. 1989. Sinopsis del género Silene L. (Caryophyllaceae) en la Península Ibérica y Baleares. Anales Jard. Bot. Madrid 45: 407-460.

Willkomm, M. \& Lange, J. 1861-1880. Prodromus florae hispanicae, 3 vols. Stuttgartiae [Stuttgart]: typis ... E. Schweizerbart. http://dx.doi.org/10.5962/bhl.title.10112 